\title{
Metrical considerations on wedding laments sung on the Šun'ga Peninsula ${ }^{1}$
}

\section{Preliminaries}

The present study considers the metrics of the laments sung in Russian on the Šun'ga Peninsula north of the Lake Onega (see Figure 1 in T. Leisiö in this volume).

Russian has phonological dynamic stress ${ }^{2}$ and it does not distinguish short and long syllables. Although stressed syllables tend to be longer than unstressed (Žirmunskij $1975,81)$, the relative duration of a vowel depends on the speaker's dialect and the speech situation. Russian poetry is typically syllabo-tonic, i.e., based on a regularly repeated number of unstressed syllables between stressed and an equal number of syllables in a foot (a regularly repeated unit of verse). Russian folk poetry is traditionally considered to have the tonic meter in which the number of stresses in a foot is stable and the number of syllables varies (ibid., 24). Russian folk verse is sung verse, thus its rhythm is determined by the rhythmical structure of the melody (ibid., 215). There are also other treatments of Russian folk poetry. Researchers of language and poetry usually account for the folk poetic text in terms of traditional meter. The musicologist A. A. Banin $(1978 ; 1982)$ suggests ignoring the role of the stress and, instead of traditional meters, addressing the syllabic rhythm of a text. John Bailey, one of those unique linguists who study the meter of lyric songs, does not deem it necessary to contrast the metrical structure of folk song with the metrical structure of written poetry and considers it necessary "to extract pure textual analogue to ensure that rhythmical analysis will be based on homogeneous texts" (Bailey 1989, 27-28).

\footnotetext{
1 Abbreviations: dim. $=$ diminutive form, $\mathrm{DAT}=$ dative, $\mathrm{PRT}=$ particle, $\mathrm{C}=$ consonant, $\mathrm{V}=$ vowel. Marks in metrical scheme: $\varnothing=$ empty mora; $0=$ non-prominent mora; $+=$ prominent mora; $o=$ half-mora, so that ' $o o^{\prime}$ forms one mora. I use the notion of metrical mora to refer to the minimal metrical unit of a poetic text.

The Cyrillic alphabet is transliterated according to the system of the Internationational Organization for Standardization (ISO). Instead of $\grave{e}$ for Cyrillic ' $\ni$ ' and $\ddot{e}$ for Cyrillic 'ë' only $e$ is in use here.

By "transcription" I refer here to the verbal text of a song while "notation" refers to melody and the poetic text written under the musical notes. All the transcriptions and notations analysed in the present research are taken from Krasnopol'skaja (1987).

2 The change of a position of a stress changes the meaning of a word.
} 
Although he makes a detailed and careful textual analysis, Bailey does not take the melody into account. The present study is an attempt to analyse folk songs on the basis of melody and poetic text. The central notion of the analysis will be the mora, which may be either filled or empty, and prominent or non-prominent.

Mora is a traditional term of metrical studies which comes from the classical Greek meter and refers to the two-way classification of syllables. A light (short) syllable $\mathrm{C}_{0} \mathrm{~V}$, where $\mathrm{V}$ is short and $\mathrm{C}_{0}$ is any string of consonants, constitutes one mora. $\mathrm{A}$ heavy (long) syllable, the one which contains a long vowel or diphthong or is closed by a consonant (string), constitutes two morae. (Prince 1989, 57.)

In Russian stichic metrics the notion of mora is not traditionally used, since Russian has no short-long syllable distinction. Studying the metrics of častuška, Nikolaj Trubetzkoj (1987/1927, 372) used the notion of musical mora ${ }^{3}$. I introduce the notion of mora to account for a minimal metric unit of a particular verse of a sung poetic text. Mora is connected to the melody, although no direct one-to-one correspondence between a musical beat and a mora can be postulated a priori. A mora is understood as the shortest time of a regular pulse, i.e., all the morae take the same unit of time when scanned. A mora can be either filled (occupied by a syllable) or empty. What I call a verse is sometimes called a line (e.g., Kiparsky \& Youmans, 1989) because one verse is usually written down in one line.

\section{Background for the sources}

By Zaonež'e (lit. 'Trans-Onega') Russian scholars refer to the Šun'ga Peninsula of Lake Onega. This peninsula protrudes from the northern shore of the lake. This part of the north-western territory of Russia is interesting in many respects: due to the history of its habitation, it has multiethnic layers. This territory has proven to be a treasurestore for folklorists: many rare pieces of folklore have been found there.

The edition Pesni Zaonež’ja v zapisjah 1880-1980 godov (edited by T. V. Krasnopol'skaja) comprises folk songs from diverse collections: (1) tape-recordings made in field work conducted 1976-1985 by students and researchers of the Petrozavodsk branch of the Leningrad Academy of Music; (2) phonograms made in 1926 during the expedition of E. V. Gippius and Z. V. Èval'd (the State Institute of the History of Arts); (3) notations made in 1916 by A. P. Maksimov from the singing of V. D. Lysanov, native of the Zaonež'e village of Sennaja Guba; (4) songs from the book Pesni russkogo naroda ('Songs of Russian folk') published in 1894 by the Russian Geographical

\footnotetext{
3 The Finnish translation of this paper of Trubetzkoy is under preparation for WWW publication within the EULA Project.
} 
Society; these songs were collected in the Archangel and Olonec areas in 1886, transcribed by F. M. Istomin and notated by composer G. O. Dütš by ear (directly from singing); (5) songs from the book Opisanie russkoj krest'janskoj svad'by... ('Description of a Russian peasant wedding') edited by O. H. Agreneva-Slavjanskaja and published in 1887-1889. The selection and notation of the songs collected in the 1970-1980s was made by Tamara V. Krasnopol'skaja and of those from the collection of 1926 by Gippius and Èval'd. In the Krasnopol'skaja's publication the songs are arranged by genre in six parts. Additionally there is an appendix which contains 18 wedding laments (pričet') (Krasnopol'skaja 1987: 142-165). These laments are subjected to analysis in the present study. All laments are indicated by Roman number VII (as done in the study by T. Leisiö in this volume) and by their arabic number: VII$1, \ldots$ VII-18.

\section{Analysis}

The poetic texts of laments under consideration demonstrate dialectal features at the phonological, morphological, lexical and syntactic levels. In particular, the place of lexical stress sometimes differs from that in Contemporary Standard Russian. There are also some characteristic textual-pragmatic features of the laments - some of them are typical of Russian folk songs in general: (1) a verse may end in an incomplete word, as if the end of the word were lost in sobbing and crying (the missing part of the word is indicated in the square brackets), (2) diminutive forms are frequently used, (3) particles (i.e., $d a$, used also as a conjunction 'and') and interjections (i.e., oj 'oh') can be often met; they belong to the style and serve for rhythmical purposes, (4) in the musical performance additional syllables may appear in consonant clusters; behind this feature there seems to be a tendency to fill every musical beat with a distinct vowel.

\section{VII-1 (Krasnopol'skaja 1987, 144-146)}

Lament VII-1 (1977, the village of Kuzaranda), ON A visit, consists of four parts, which will be marked here by A, B, C and D. All these parts used to be performed when the bride visited her relatives (her last visits as an unmarried girl). The bride performs part A ( 9 verses) at the entrance of the house of her aunt, being about to step inside. Part B ( 9 verses) is lamented by the bride to her aunt after the visit: the bride bids farewell to her aunt. In part C (14 verses) the bride thanks for the presents. In part $\mathrm{D}$ (24 verses) having returned home she tells her parents that she has lost her free will. On the whole the 56 verses of Lament VII-1 are transcribed and the musical notation is presented for part A. For the illustration of the metrical scheme of this lament I have chosen the verses representing possible variations of empty and filled morae. 


\section{(1) VII-1}

\section{Comments:}

In all the extracts of the present study, the syllable division differs from that used in Krasnopol'skaja 1987 and corresponds to the acoustic syllable division of Russian, which is based on the principle of rising sonority (Rozental' 1979, 89). In the text transcription I show all lexical stresses. In the tables containing metrical scheme only the prominent morae are stressed. In translation some forms are marked which are typical of laments (see Abbreviations in footnote 1). In Krasnopol'skaja 1987 nonlexical syllables (those which appear in singing) are not marked in the text transcription but only in the text under the notation. In the text examples I put the additional vowels into the brackets while in the metrical tables these syllables are without brackets. First the verses are presented and translated. After that the same verses are repeated in the table, the metrical scheme following each verse in the row directly beneath. Under each syllable, a subscribed number $\left(\mathrm{bo}_{1}, \mathrm{do}_{2}\right.$, etc.) indicates the number of musical beats this syllable takes in musical time. In this lament a musical beat is $1 /$ 8 note long. The subscription of musical beats is only presented in the examples in which a correspondence between metrical mora and musical beat takes place.

\begin{tabular}{|c|c|c|}
\hline VERSE & TEXT & COMMENTS \\
\hline \multirow{2}{*}{$\begin{array}{l}\mathrm{A} / 1(\text { part A, } \\
\text { verse } 1)\end{array}$} & Slá-va bó-gu-š(i)-ku ti-pér' da slá-va gó-[spo-du] & \multirow{4}{*}{$\begin{array}{l}\text { In notation of verse } \mathrm{A} / 6 \text { only the } \\
\text { first syllable of the last (incomplete) } \\
\text { word is presented while in the tran- } \\
\text { scription there are two first syllables. }\end{array}$} \\
\hline & Glory to the God.dim now PRT glory to the God & \\
\hline \multirow[t]{2}{*}{$\mathrm{A} / 6$} & oj ver-no tú-t(y) ži-vét ža-lán-na da mi-la té-ti[n'-ka] & \\
\hline & Oh apparently it is here where my beloved dear Auntie.dim lives & \\
\hline \multirow[t]{2}{*}{$\mathrm{B} / 9$} & é-ta ptí-če-n(i)-ka ba-žó-na mo-já vó-lju-ška & \multirow{4}{*}{$\begin{array}{l}\text { Verse } \mathrm{B} / 9 \text { is the last one in lament } \\
\mathrm{B} \text {. Probably this is is the reason why } \\
\text { the last word of this verse is com- } \\
\text { pletely performed. }\end{array}$} \\
\hline & This bird.dim is my desired will.dim & \\
\hline \multirow[t]{2}{*}{$\mathrm{D} / 13$} & oj čtó-by dó-gna-li ba-žó-nu da mo-ju vó-[lu-šku] & \\
\hline & oh in order to catch my PRT desired will.dim & \\
\hline
\end{tabular}

\begin{tabular}{|c|c|c|c|c|c|c|c|c|c|c|c|c|c|c|c|}
\hline \multirow[t]{2}{*}{$\mathrm{A} / 1$} & & $\mathrm{Sla}_{1}-$ & $\mathrm{va}_{2}$ & bó $_{1}-$ & $\mathrm{gu}_{1}-$ & $\check{s} i_{1}-$ & $\mathrm{ku}_{1}$ & $\mathrm{ti}_{2-}$ & pér' & $\mathrm{da}_{2}$ & & sla $_{1}-$ & $\mathrm{va}_{2}$ & gó $_{1}-$ & \\
\hline & $\varnothing$ & 0 & $0 \varnothing$ & + & 0 & 0 & 0 & $0 \varnothing$ & + & 0 & $\varnothing$ & 0 & 00 & + & $\varnothing$ \\
\hline \multirow[t]{2}{*}{$\mathrm{A} / 6$} & $\mathrm{oj}_{1}$ & ver $_{1}-$ & $\mathrm{no}_{2}$ & $\mathrm{tú}_{1}-$ & $t y_{1}$ & $\check{z} i_{1_{1}}-$ & vët ${ }_{1}$ & $\mathrm{ža}_{2}-$ & lán ${ }_{1}-$ & $\mathrm{na}_{1}$ & $\mathrm{da}_{1}$ & $\mathrm{mi}_{1}-$ & $\mathrm{la}_{2}$ & té $e_{1}$ & $t i_{1}-$ \\
\hline & 0 & 0 & 00 & + & 0 & 0 & 0 & $0 \varnothing$ & + & 0 & 0 & 0 & $0 \varnothing$ & + & 0 \\
\hline \multirow[t]{2}{*}{$\mathrm{B} / 9$} & & $e_{1}-$ & $\mathrm{ta}_{2}$ & pti $i_{1-}^{-}$ & $\mathrm{cre}_{1}-$ & $\mathrm{ni}_{1}-$ & $\mathrm{ka}_{1}$ & $\mathrm{ba}_{2}-$ & žó $_{1}-$ & $\mathrm{na}_{2}$ & & $\mathrm{mo}_{1}^{-}$ & $\mathrm{ja}_{2}$ & $\mathrm{vo}_{1}{ }^{-}$ & $\operatorname{lju}_{1^{-}}$ \\
\hline & $\emptyset$ & 0 & 00 & + & 0 & 0 & 0 & 00 & + & 0 & $\varnothing$ & 0 & $0 \varnothing$ & + & 0 \\
\hline \multirow{2}{*}{$\begin{array}{l}\mathrm{D} / 1 \\
3\end{array}$} & $0 j_{1}$ & čto $_{1-}$ & $\mathrm{by}_{2}$ & dó $_{1}$ - & gna $_{2}-$ & & $\mathrm{li}_{1}$ & $\mathrm{ba}_{2}-$ & žó $_{1}-$ & $\mathrm{nu}_{1}$ & $\mathrm{da}_{1}$ & $\mathrm{mo}_{1}-$ & $\mathrm{ju}_{2}$ & vó $_{1-}$ & \\
\hline & 0 & 0 & $0 \varnothing$ & + & 0 & $\varnothing$ & 0 & $0 \varnothing$ & + & 0 & 0 & 0 & $0 \varnothing$ & + & $\varnothing$ \\
\hline
\end{tabular}

The procedures of developing of metrical schemes are as follows. The metrical scheme is based on the poetic and musical texts. Prominent morae correspond to the musical prominences: they are often the initial sounds of a bar, sometimes they sound longer than the surrounding morae, or (/and) the intervals are prominent from the viewpoint of a textual structure. Additionally the prominent morae always coincide with stressed syllables of lexical words (nouns, verbs, adverbs, and adjectives) which are contextu- 
ally important. The positions of non-prominent morae, filled or empty, are correlated in all the verses available of a particular song. An empty mora often appears to be filled by a syllable in the next verse. An empty mora may be either a part of drawn out syllable or silant.

In Lament VII-1 one metrical mora corresponds to one musical beat (1/8 note). Such one-to-one correspondence is rather an exception than a rule. The scheme of this lament shows that the verse is 18 morae long, it contains 3 prominences, which are the 5th, the 11th and the 17th morae, and there are 5 non-prominent morae in-between. A prominent mora is always preceded by an empty mora. This means that a prominence-preceding mora sounds twice longer than a prominent mora. In the musical notation there are two pauses (1/8 long) at the end of each verse. Nevertheless, I have indicated only one empty mora at the end of a verse for the following two reasons: (1) the final position of a verse is always more prominent than a medial one, and in many genres and ways of performance of folk songs, sounds tend to draw out toward the end of a verse; there is no need to mark this drawing-out in a metrical scheme, (2) only one empty mora at the end provides the recurring metrical pattern $+00000+$ (five non-prominent morae between two prominent morae) which is also realised in the shift from a verse to the next one:

The end of a verse: $\quad+\varnothing$

The start of the next verse: $0000+$

Thus the distance of five non-prominent morae is retained between the verses. Two non-prominent morae at the end of a verse appear twice, both times in the last verse of the part, in verses B/9 vó-lju-ška and D/24 vó-lju-škoj 'will'.dim. These two are also the only cases of the appearance of complete words at the end of a verse. Noun voljuška 'will' is a key-word of the bride's parts of the lament.

In the example above we can find additional syllables, formed through the interpolation of vowels in consonant clusters. As the result of interpolation each musical beat is occupied by a syllable. For instance, $b o-g u$-šku 'God'.dim.DAT is sung with the additional vowel $/ i /$, bo-gu-ši-ku (verse A/1). The new non-lexical syllable and the next one, $-\check{s} i-k u$, take one $1 / 8$ beat each.

\section{VII-2 (Krasnopol'skaja 1987, 146-147)}

Lament VII-2 BAJNA 'Sauna' (1977, Kuzaranda) has the same metrical scheme as Lament VII-1. Of this lament 21 verses are transcribed and 9 verses notated. The first and the last prominences are the 5 th and the 17 th morae respectively. These prominences are regularly preceded by an empty mora, which means that the pre-prominence syllable is two morae long. The second prominence, the 11th mora, is also always pre- 
ceded by an empty mora except in one verse, in which this mora is filled by a syllable. The metrical scheme of this lament is illustrated by verse 4 below. For comparison the metrical scheme of Lament VII-1 is repeated (row 3). It is important to note that the metrical mora of Lament VII-2 corresponds to the 1/8-note long musical beat quite like in Lament VII-1.

\section{(2) VII-2, verse 4}

Oj, tut pri-šlá ja vo te-plu-par-nu da vé-tu ba-[enku]

Oh, now I have come to this warm sauna.dim

\begin{tabular}{|l|l|l|l|l|l|l|l|l|l|l|l|l|l|l|l|}
\hline \multirow{2}{*}{$\begin{array}{l}\text { VII- } \\
\mathbf{2 , 2}\end{array}$} & oj $_{1}$ & tut $_{1}$ & pri $_{2^{-}}$ & s̆lá $_{1}$ & $\mathrm{ja}_{1}$ & $\mathrm{vo}_{1}$ & $\mathrm{te}_{1^{-}}$ & $\mathrm{plu}_{2^{-}}$ & $\mathrm{pá}_{1^{-}}$ & $\mathrm{nu}_{1}$ & $\mathrm{da}_{1}$ & $\mathrm{ve} \mathrm{e}_{1^{-}}$ & $\mathrm{tu}_{2^{-}}$ & bá $_{1^{-}}$ & \\
\hline VII-1 & $\varnothing$ & 0 & $0 \varnothing$ & + & 0 & 0 & 0 & $0 \varnothing$ & + & 0 & 0 & 0 & $0 \emptyset$ & + & $\emptyset$ \\
\hline
\end{tabular}

It is easy to see that the metrical patterns of Lament VII-1 and Lament VII-2 are precisely the same: in both laments there are five non-prominent morae between prominences and three prominences in a verse, the 1 st in the position of the 5th mora from the beginning and the last in the position of the 2nd mora from the end of a verse. Both laments were recorded during the same field work in 1977 in the same village from the same singer, which facts may explain the similarity of the performance style.

\section{VII-3 and VII-4 (Krasnopol'skaja 1987, 147-149)}

Laments VII-3 Mother AWAKENS THE BRIDE and VII-4 BIDDING FAREWELL TO FREE WILL were recorded at the same time (1984) and performed by the same woman in the village of Pajanicy. Their metrical scheme is the same as that of the Laments VII-1 and VII-2. Laments VII-3 and VII-4 also have the equivalence of a mora to a beat except in the position of the 15th-16th mora, which is drawn out and, compared to the number of morae, requires two (in VII-3) and one (in VII-4) additional beats. In each verse, the drawn out mora precedes the final prominence. This can be seen in the meters of Laments, $(4+6+8+3) / 8$ in VII-3 and $(4+6+7+3) / 8$ in VII-4. The third bar is in VII-3 a 1/4 note longer and in VII- 4 a 1/8 note longer than is the 2 nd bar. The schemes of these two laments are shown below:

(3) VII-3, verse 5

Ija ne pé-r(y)-voj ra-z(y) bu-žú a ja v po-s(y)-lé-[dnij raz]

And I do not awaken you for the first time but for the la[st time]

\begin{tabular}{|c|c|c|c|c|c|c|c|c|c|c|c|c|c|c|c|c|c|}
\hline $\mathrm{i}$ & ja & & ne & pé- & ry- & voj & ra- & zy & bu- & žú & & $\mathrm{a}$ & $\mathrm{ja}$ & v po- & sy- & lé- & \\
\hline 0 & 0 & $\varnothing$ & 0 & + & 0 & 0 & 0 & 0 & 0 & + & $\varnothing$ & 0 & 0 & 0 & 0 & + & $\varnothing$ \\
\hline
\end{tabular}




\section{VII-4, verse 4}

I ne u-s(y)-lý-šiš’ ty bó-l(e)-še gó-lo-sa ma-é-[go]

And you will never hear my voice

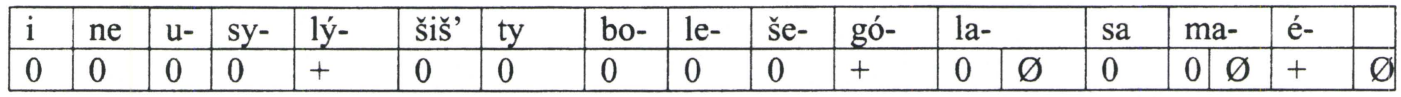

Thus the metrical pattern of these laments is 5 non-prominent morae between prominences. The pattern recurs at the beginning of the next verse: there are five nonprominent morae between the final prominence of verse $\mathrm{N}$ and the first prominence of verse $(\mathrm{N}+1)$.

\section{Lament VII-5 (Krasnopol'skaja 1987, 150)}

In Lament VII-5, ON RETURN FROM THE VISIT (1976, Tolvuja village), 3 verses are notated and 17 verses transcribed. This lament has the same content as part D of Lament VII1. The verse structures of VII-1/D and VII-5 are similar, with one systematic change: in VII-1/D each verse starts with the interjection oj! and ends in an uncompleted word, while in Lament VII-5 there are no interjections and verse-final words are complete. The first verses of the two laments are very close. Consider the examples below:

\section{(4) VII-1, part D, verse 1}

Oj, nahodilas' ja, krasa devuška, nagulja-...

Oh I, young girl, have walked enough and I have had enough good times

\section{VII-5, verse 1}

Nahodilas' ja, krasna devuška, naguljalasja.

We can deduce the scheme of Lament VII- 5 from the scheme of Lament VII-1 by starting from the three (instead of four) non-prominent morae and ending in two (instead of one) non-prominent morae. This scheme really functions for all the verses of VII-5:

\section{(5)}

\begin{tabular}{|c|c|c|c|c|c|c|c|c|c|c|c|c|c|c|c|c|}
\hline \multirow{2}{*}{$\begin{array}{l}\text { VII- } \\
1\end{array}$} & oj & na- & ho- & dí- & las' & ja & kra- & sa & dé- & vu- & ška & na- & gu- & ljá- & & \\
\hline & 0 & 0 & $0 \varnothing$ & + & 0 & 0 & 0 & $0 \varnothing$ & + & 0 & 0 & $0 \varnothing$ & 0 & + & $\varnothing$ & \\
\hline \multirow{2}{*}{$\begin{array}{l}\text { VII- } \\
5\end{array}$} & & na- & ho- & dí- & las' & ja & kra- & sna & dé- & vu- & ška & na- & gu- & ljá- & la- & sja \\
\hline & & $0 \varnothing$ & 0 & + & 0 & 0 & $0 \varnothing$ & 0 & + & 0 & 0 & 0 & $0 \varnothing$ & + & 0 & 0 \\
\hline
\end{tabular}

For VII-5 the pattern regularly repeated throughout the lament can be distinguished as $(000+00)$, while the pattern of VII- 1 is $(0000+0)$. 


\section{VII-6 and VII-7 (Krasnopol'skaja 1987, 151-152)}

Laments VII-6 and VII-7 are taken from Agreneva-Slavjanskaja 1887. In Lament VII6 one verse is notated and 17 verses transcribed. In Lament VII-7 one verse is notated and 55 transcribed. These two laments were performed by the famous Russian lamenter I. A. Fedosova (the village of Kuzoranda) and notated by ear. Concluding from the headings, both laments, VII-6 BRIDE'S LAMENT ON HER GIRL FRIENDS' COMING and VII-7 BRIDE'S LAMENT ON HER VISITING RELATIVES, are performed by the bride. Nevertheless text analysis of Lament VII-7 permits another conclusion. The first 26 verses do belong to the bride: she says she stepped into her sister's house and describes the entrance as being refurbished and everything being ready to shoot her (bride's) will (every following step in the ritual brings closer the final loss of the bride's free will). Then the bride tells her sister not to be afraid: the bride is accompanied by the flight of geese and swans. From verse 27 to the end of the transcription the lamenter is the bride's sister: she welcomes the flight of geese and swans inside to the refurbished dining room. Then she asks the bride to step onto the porch: the floor will not bend and the bride's will won't be betrayed (the bride's will will thus be left in the bride's sister's house). Then the sister asks the bride to come inside and to sit down at the oak tables.

In Lament VII-6 the verse varies from 9 to 18 syllables. The variation is still not chaotic but systematic. The basic verse is 14 morae long and takes 11-14 syllables. The 18 syllables long verse can be divided into two hemistichs each 9+9 syllables long, as shown below by a vertical line:

(6) VII-6, verse 11

Kak se-gó-dnja, segó de-né-čka I mo-já vó-lja i-zme-njá-e-tsja As today, this day I my will is changing

Although syllabically shorter than others, 9-syllable verses can be performed as 14 morae long. Another possibility is to perform them as 9 morae long. In both cases the number of non-prominent morae between prominences remains permanent. The metrical scheme of Lament VII-6 is exemplified below with the 1st and the 12th verses, the latter with two possibilities of performance. In notation of the 1st verse (musical meter $7 / 4)$ there are 4 bars: $1 / 8+1 / 8,(1 / 8+1 / 8+1 / 8+1 / 8) \times 2,1 / 4+1 / 4$. Thus each syllable is $1 / 8$ long, except two last syllables which are $1 / 4$ long:

(7) VII-6, verse 1

To ne pti-cyn'-ka so gné-zdy-ška sle-tá-et

It is not a bird.dim flying from the nest 


\section{Verse 12}

Kra-so-tá s li-cá te-rjá-e-tsja

Beauty disappears from the face

\begin{tabular}{|c|c|c|c|c|c|c|c|c|c|c|c|c|c|c|}
\hline \multirow[t]{2}{*}{ verse 1} & to & ne & ptí- & cyn'- & $\mathrm{ka}$ & so & gné- & zdy- & ška & sle- & tá & & et & \\
\hline & 0 & 0 & + & 0 & 0 & 0 & + & 0 & 0 & 0 & + & $\varnothing$ & 0 & (Ø) \\
\hline \multirow{2}{*}{$\begin{array}{l}\text { verse } 12 \\
9 \text { morae } \\
\end{array}$} & kra- & so- & tá & s li- & $\mathrm{ca}$ & te- & rjá- & e- & tsja & & & & & \\
\hline & 0 & 0 & + & 0 & 0 & 0 & + & 0 & 0 & & & & & \\
\hline \multirow{2}{*}{$\begin{array}{l}\text { verse } 12 \\
14 \text { morae }\end{array}$} & kra- & so- & tá & & s li- & & cá & & te- & & rjá- & & et- & sja \\
\hline & 0 & 0 & + & $\varnothing$ & 0 & $\varnothing$ & + & $\varnothing$ & 0 & $\varnothing$ & + & $\varnothing$ & 0 & 0 \\
\hline
\end{tabular}

Thus the scheme of this lament is based on three non-prominent morae between prominences. It is also possible to suggest other ways to perform a short verse in 14 morae. But theoretical possibilities do not help: we still can not go back 120 years and listen to the performer. The most important result is that the backbone of the metrical scheme remains the same in all the types of performance: three non-prominent morae are kept between two prominences. The metrical scheme of this lament does recur, as was the case in Laments VII-1, VII-3 and VII-4, but starts from the beginning with each new verse.

The meter of Lament VII-7 is also 7/4. The division into bars differs from that of VII-6 in one respect: the two middle bars of Lament VII-6 correspond to one bar of Lament VII-7. The verse of Lament VII-7 contains 8-15 syllables with a typical length of 9-10 syllables. In verse 1 (10 syllables), there are 7 non-prominent morae between prominences. In both laments a metrical mora corresponds to a 1/8-note musical beat and thus a verse is 14 morae long: in the case of one-to-one correspondence between a musical beat and a metrical mora the metrical duration is deducable from musical duration, for these two laments $7 \times 2=14$. There are three prominences in the prototypically 14-mora verse of Lament VII-6, while there are two prominences in the prototypically 9-mora verse of Lament VII-7. If a verse has more than 10 syllables there can be three prominences, as it is demonstrated below on verses 19 and 40 .

(8) VII-7, verse 1

Dó-bry kó-nju-ški po-usto-já-lis',

Good horses.dim stopped to stay,

Verses 18-19

S Mo-skvý pló-tni-cki na-ni-má-ny,

Carpenters.dim were hired from Moscow

vo vy-só-ko kry-lé-cko po-dni-má-ny.

and brought to the high porch.dim.

\begin{tabular}{|l|l|l|l|l|l|l|l|l|l|l|l|l|l|l|l|}
\hline 1 & do- & bry & kó- & & nju- & & ški & po- & u- & sto- & já- & & lis' & \\
\hline & 0 & 0 & + & $\varnothing$ & 0 & $\varnothing$ & 0 & 0 & 0 & 0 & + & $\varnothing$ & 0 & $\varnothing$ \\
\hline 18 & s mo- & skvy & pló- & & tni- & & čki & na- & & ni- & má- & & ny & \\
\hline & 0 & 0 & + & $\varnothing$ & 0 & $\varnothing$ & 0 & 0 & $\varnothing$ & 0 & + & $\varnothing$ & 0 & $\varnothing$ \\
\hline 19 & vo & vy- & só- & ko & kry- & & lé- & čko & po- & dni- & má- & & ny & \\
\hline & 0 & 0 & + & 0 & 0 & $\varnothing$ & + & 0 & 0 & 0 & + & $\varnothing$ & 0 & $\varnothing$ \\
\hline
\end{tabular}


Verse 40 (the bride's sister laments)

Ne iz-me-njú tvo-éj vó-le, vól'-noj vó-lju-ške.

I will not betray your will, your free will.dim.

Verses 53-54

Ty sa-dís' li, mo-já bé-la-ja le-bé-du-ška,

Sit down, my white swan.dim,

za sto-lý du-bó-vy-i, na stú-l'i-ca kle-nó-vy-e.

at the oak tables, on the maple chairs.dim.

\begin{tabular}{|l|l|l|l|l|l|l|l|l|l|l|l|l|l|l|}
\hline 40 & ne & i- & zmé- & nju & tvo- & ej & vó- & le & vol'- & noj & vó- & lju & ške & \\
\hline & 0 & 0 & + & 0 & 0 & 0 & + & 0 & 0 & 0 & + & 0 & 0 & $\varnothing$ \\
\hline 53 & ty & sa- & dís' & li & mo- & ja & bé- & la- & ja & le- & bé- & du- & ška & \\
\hline & 0 & 0 & + & 0 & 0 & 0 & + & 0 & 0 & 0 & + & 0 & 0 & $\varnothing$ \\
\hline 54 & za & sto- & lý & du-bo- & vy-i & na & stú- & l'i- & ca & kle- & nó- & vy- & i & \\
\hline & 0 & 0 & + & oo & oo & 0 & + & 0 & 0 & 0 & + & 0 & 0 & $\varnothing$ \\
\hline
\end{tabular}

The stress position of the first word of the verse 40 is changed from the 4 th to the $3 \mathrm{rd}$ syllable. There are three non-prominent morae between prominences. The positions of the first and the last prominences are permanent: the third mora from the beginning and the fourth mora from the end. Thus, the scheme is the same as in VII-6, with one exception: in VII-7 the medial prominent mora (the 7th mora from the beginning) is sometimes lacking (e.g., verse 18) - in this case there are seven non-prominent morae between the prominences.

\section{VII-8 (Krasnopol'skaja 1987, 152-153)}

In Lament VII-8 (1977, the village of Vëgoruksy), ON A visit, the bride laments to her Godmother. There are 14 verses transcribed and notated. A metrical mora has no oneto-one correspondence to a musical beat. A verse is 13 morae long. In a verse, there are three prominences, the $3 \mathrm{rd}$ and the 7 th morae from the beginning and the 3rd mora from the end. Consider the 13th verse:

(9) VII-8, verse 13 (A bride asks her Godmother)

Ty pri-dáj mne u-má-rá-zu-ma v(y) go-ló-vu-šku.

Give me wits in my head.dim

\begin{tabular}{|l|l|l|l|l|l|l|l|l|l|l|l|l|l|}
\hline verse 13 & Ty & pri- & dáj & mne & u- & ma- & rá- & zu- & ma & vy go- & ló- & vu- & šku \\
\hline scheme & 0 & 0 & + & 0 & 0 & 0 & + & 0 & 0 & oo & + & 0 & 0 \\
\hline mora No: & 1 & 2 & 3 & 4 & 5 & 6 & 7 & 8 & 9 & 10 & 11 & 12 & 13 \\
\hline
\end{tabular}

In verse 13 the two syllables preceding the last prominence constitute one mora. The distance between prominences is 3 non-prominent morae. There are a few verses in which the distance between prominences is 5 non-prominent morae instead of 3 : 
(10) Verses 1-2

Slá-va bó-gu da slá-va mí-lo-sti-voj gó-spo-di,

Gloria to God, gloria, God Gracious, put'-do-ró-žen'-ka da s(y)-ko-ro-tá-la-si the travel.dim is finished.

\begin{tabular}{|l|l|l|l|l|l|l|l|l|l|l|l|l|l|}
\hline Sla- & va & bó & gu & da & sla- & va & mí- & lo- & sti- & voj & gó- & spo- & di, \\
\hline 0 & 0 & + & 0 & 0 & $0 \varnothing$ & 0 & + & 0 & 0 & 0 & + & 0 & 0 \\
\hline put'- & do- & ró- & žen'- & ka & da sy- & ko- & ro- & & tá- & la- & si \\
\hline 0 & 0 & + & 0 & 0 & o o & 0 & 0 & & + & 0 & 0 \\
\hline
\end{tabular}

In verse 1 there are 3 prominences with 5 and 3 non-prominent morae between them, and in verse 2 there are two prominent morae with 5 non-prominent morae inbetween. In all the verses, the first prominence is the third mora from the beginning and the final prominence is the third mora from the end.

\section{VII-9 (Krasnopol'skaja 1987, 154)}

Lament VII-9, THE BRIDE LAMENTS TO HER PARENTS AFTER THEIR ACCEPTING THE PROPOSAL, was performed in 1886 in the village of Sennaja Guba. Of this lament there are 74 verses transcribed and verses 1-2 notated. Each verse ends in an uncompleted word, interrupted on a stressed syllable. The rest of a word - the two last syllables - is presented in square brackets. In the notation the missing syllables are 1/8 note long. The length of a verse (including the missing syllables) varies from 8 to 15 syllables. A prototypical verse has 9 or 13 syllables. In notation the verse is divided into three bars. The musical meter is $(1+5+3) / 4$. The metrical scheme with possible variations is presented below:

\section{(11) VII-9, verse 1}

Mne-ka smet' li krá-snoj dé-[vu-ški]

May I, young girl, dare

Verse 40

Mne ne pó ljubi a cju-ža-dál'-nja-ja sto-ró-nu-ška

I do not want to go to the unknown far side

Verse 54

Vy po-slú-šaj-te, že-lán-ny-e ro-di-te-li

Listen to me please, my dear parents.

\begin{tabular}{|l|l|l|l|l|l|l|l|l|l|l|l|l|l|l|l|}
\hline 1 & mne- & ka & smet' & li & kra- & noj & dé- & {$[$ vu- } & ški $]$ & & & & & & \\
\hline & 0 & 0 & + & 0 & 0 & 0 & + & {$[0$} & $0]$ & & & & & & \\
\hline 40 & mne & ne & pó & lju- & bi & a & cju- & za- & dál'- & nja- & ja & sto- & ró- & [nu- & ška] \\
\hline & 0 & 0 & + & 0 & 0 & 0 & 0 & 0 & + & 0 & 0 & 0 & + & 0 & 0 \\
\hline 54 & vy & po- & slú- & šaj- & te & že- & lán- & ny- & e & ro- & di- & [te- & li] & & \\
\hline & 0 & 0 & + & 0 & 0 & 0 & + & 0 & 0 & 0 & + & 0 & 0 & & \\
\hline
\end{tabular}


Verse 40 has 5 non-prominent morae between the 1 st and the 2 nd prominences. A typical distance between the prominences is 3 non-prominent morae. The first and the final prominences have permanent positions which are the third mora from the beginning and the third mora from the end.

\section{VII-10 (Krasnopol'skaja 1987, 155)}

Lament VII-10 (1886, the village of Sennaja Guba), THE BRIDE ADDRESSES THE GROOM ASKING FOR PRESENTS FOR HER RELATIVES, is from the same collection and the same performer as Lament VII-9. Two verses are notated and 42 transcribed. The prototypical verse of this lament contains 9 syllable. Out of 42 verses there are twenty seven 9syllable verses, six 18-syllable verses, three 10-syllable verses, two 8-syllable verses, two 17-syllable, one 19-syllable and one 13-syllable verse. The verses which are 18syllables always have a clearly distinguishable syntactic border which divides the verse into two hemistichs, each 9 syllables long. Thus 18- (and, in its variations, 17and 19-) -syllable verses should fit a doubled metrical scheme for 9 syllables. The two notated verses, especially the second one, actually deviate most from the metrical scheme. These two verses have special discourse purposes: the bride addresses God and begs Him to bless her in a holy moment. The next verses are quite different in content. The metrical scheme of this lament is illustrated by verse 1,2 and 4 , the latter presented in two hemistichs of 9+9 syllables.

(12) VII-10 (the musical meter is 4/4), verses 1-2

Gó-spo-di da bó-že bla-go-slo-ví,

God, bless

bó-že, bla-go-slo-ví vo svja-tój cjas v kóž-no vré-[mec'ko]

God bless in the holy hour

Verse 4

Za mo-ím sto-lóm du-bó-vy-im si-dját gó-sti ne-zna-kó-my-i

Infamiliar guests are sitting at my oak table

\begin{tabular}{|c|c|c|c|c|c|c|c|c|c|c|c|c|c|c|}
\hline 1 & go- & spo- & dí & \multicolumn{2}{|l|}{ da } & bo- & \multicolumn{2}{|l|}{ že } & bla- & & go- & slo- & ví & \\
\hline & 0 & 0 & + & 0 & & 0 & \multicolumn{2}{|l|}{0} & + & $\varnothing$ & 0 & 0 & + & \\
\hline \multirow[t]{2}{*}{2} & bo- & že & blá- & go- & slo- & vi & vo & svja- & tój & cjas & v kož- & no & vre- & [mec'ko] \\
\hline & 0 & 0 & + & o & 0 & 0 & o & $\mathrm{o}$ & + & 0 & 0 & 0 & + & \\
\hline \multirow[t]{2}{*}{4} & $\mathrm{za}$ & mo- & im & \multicolumn{2}{|l|}{ sto- } & lom & \multicolumn{2}{|l|}{ du- } & bó- & vy & im & & & \\
\hline & 0 & 0 & + & \multicolumn{2}{|l|}{0} & 0 & \multicolumn{2}{|l|}{0} & + & 0 & 0 & & & \\
\hline \multirow[t]{2}{*}{4} & si- & djat & gó- & \multirow{2}{*}{\multicolumn{2}{|c|}{ sti }} & ne- & \multirow{2}{*}{\multicolumn{2}{|c|}{ zna- }} & kó- & my- & $\mathrm{i}$ & & & \\
\hline & 0 & 0 & + & & & 0 & & & + & 0 & 0 & & & \\
\hline
\end{tabular}

The shift of lexical stress has occurred from the first to the last syllable of the 1st word of verse 1 and from the last to the first syllable of the 2 nd word of the verse 2 .

In a short (9-syllable) verse there are 2 prominences and in a long (18-syllable) 
verse there are twice as many, 4 prominences. Between prominences there are three non-prominent morae. The first prominence is the third mora from the beginning and the final prominence is the third mora from the end of a verse. The only exception is the first verse of the lament. The verses which complete 9+9 morae should be considered as two verses. The metrical scheme does not recur between verses, - between the final prominence of a verse and the first prominence of the next verse there are four (and not three) non-prominent morae.

\section{VII-11 (Krasnopol'skaja 1987, 155-156)}

Lament VII-11 (1975, the village of Velikaja Niva), consists of three parts, THE BRIDE ASKS HER MOTHER FOR PERMISSION TO VISIT HER AUNT, THE AUNT MEETS THE BRIDE, RETURNING HOME THE BRIDE ADDRESSES HER MOTHER. Of this lament, 23 verses are transcribed and 10 notated. The notated verses complete three or four bars, and the meter changes from verse to verse. The bride's parts of the lament (in total 13 verses) consist of 9-10 syllable verses. In the aunt's part, there are longer verses. In this lament, the correspondence between syllable, metrical mora and musical beat (1/8 note) is direct and unequivocal, and almost every syllable takes one beat. The number of non-prominent morae between prominences varies. The first and the final prominences of a verse have stable positions, the fourth mora from the beginning and the fourth mora from the end. The last musical beat always corresponds to an empty mora. Thus the final prominence is the 3rd filled mora from the end. In the first two verses of the lament the final prominence is the fifth mora from the end. The verses of 9-12 syllables have two prominences. The distance between the prominences varies from 3 to 5 morae. Longer verses (in the aunt's part of the lament) have three prominences. The metrical scheme and its variations are exemplified below with the verses $1-3$ (the bride's part) and 9-10 (the aunt's part).

\section{(13) Lament VII-11, Verses 1-3}

Oj ty spu-stí, ro-dí-tel'-mátu-š( $(i)-k a$,

oj, ko ro-dí-moj ko té-tin'-ke

vo lju-bi-mo vo go-stí-bi-šče.

Oh, my parent-mother.dim, let me go

oh, to my dear aunt

to my beloved visiting place.

Verses 9-10

oj, hú-do sdé-la-la ty,vo-zljú-blen-na krá-sna dé-vu-ška,

oj, ne po-slú-ha-la ro-dí-te-li-to má-tu-ški.

Oh you, my beloved young girl, have done a bad deal

that you have not obeyed your parent-mother.dim 


\begin{tabular}{|l|l|}
\hline Verse & Musical meter: \\
\hline 1 & $3+4+5 / 8$ \\
\hline 2 & $3+3+5 / 8$ \\
\hline 3 & $3+5+4 / 8$ \\
\hline 9 & $3+5+6+4 / 8$ \\
\hline 10 & $3+4+4+4 / 8$ \\
\hline
\end{tabular}

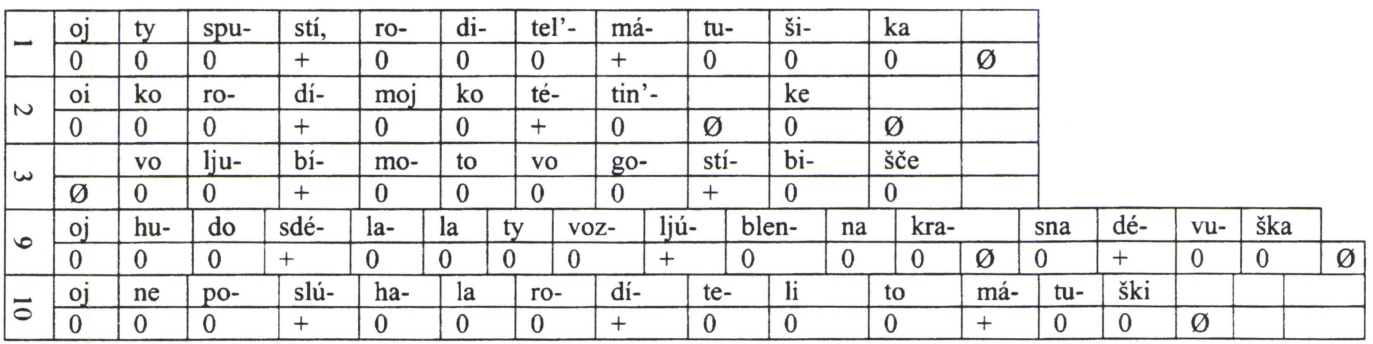

As shown above, in verse 9 there are four non-prominent morae between the 1 st and the 2 nd prominences and five non-prominent morae between the 2 nd and the $3 \mathrm{rd}$ prominences. In verse 2 there are two morae between the prominences. On the whole Lament VII-11 comes close to Finnic laments, with their varying number of syllables in a verse.

\section{VII-12 (Krasnopol'skaja 1987, 157-158)}

In Lament VII-12 there are 36 verses transcribed and the 6 first verses notated. A bride laments to her family, addresses her mother and brother and bids farewell to them. This lament was performed by the same lamenter as Lament VII-11. Both laments were recorded in 1975. Nevertheless, the style of the performance differs: in Lament VII-12 some syllables have 1/8 note duration while the others, in the same position in another verse, are drawn out. Thus there is no one-to-one correspondence between metrical mora and musical beat. As in the preceding lament, the musical meter varies. The first prominence is the fourth mora from the beginning (the only exception is the fifth prominent mora in verse 5). The final prominence is the third mora from the end. An initial word which mostly consists of one syllable is the interjection oj 'oh', the conjunctions $d a$ 'and', ved' 'since', kak 'how', and čto 'that', the particle ne 'not', or the prepositions po 'along' and $u$ 'by/at'. The middle prominence is mostly the seventh mora and, in a long verse, also the eleventh mora. There typically are 3 non-prominent morae between prominences. Of 36 transcribed verses, 17 consist of 10 syllables. There are also 12- and 14-syllable verses (5 verses of each), 9syllable verses ( 3 verses), 15- and 11-syllable verses ( 2 verses of each), as well as 8and 16-syllable verses (one verse of each).

The metrical scheme is illustrated below with the verses $2-3$ and $10-11$. 
(14) verses $2-3$

Oj, ja vo pó-če-s(y)-noj vo ból'-šoj ú-go-l(y) sho-dí[la]

oj, na sve-tí-te-lej gla-zá pe-re-k(y)-re-stí[la]

I have been to the icon corner (in the house)

and I have crossed myself before the Saints.

Verses 10-11

oj, gde-to est' u me-njá, u o-bí-dnoj krá-snoj dé-vu-ški,

oj, tam ro-dí-tel' mo-ja má-tu-ška

I, sad young girl, have somewhere

my parent - my mother

\begin{tabular}{|l|l|l|l|l|l|l|l|l|l|l|l|l|l|l|l|l|}
\hline 2 & Oj & vo & po- & čé- & sy- & noj & vo & bol'- & šój & u- & go- & ly & sho- & dí- & & \\
\hline & 0 & 0 & 0 & + & o & o & 0 & 0 & + & 0 & o & o & 0 & + & $\emptyset$ & $\emptyset$ \\
\hline 3 & oj & na & sve- & tí- & te- & & lej & gla- & zá & pe- & re- & ky- & re- & stí- & $\emptyset$ & $\emptyset$ \\
\hline & 0 & 0 & 0 & + & 0 & & 0 & 0 & + & 0 & o & o & 0 & + & 0 & \\
\hline 10 & oj & gde- & to & ést' & u & me- & nja & u & o- & bí- & dnoj & kra- & noj & dé- & vu- & ški \\
\hline & 0 & 0 & 0 & + & o & o & o & o & 0 & + & 0 & 0 & 0 & + & 0 & 0 \\
\hline 11 & oj & tam & ro- & di- & tel' & mo- & ja & má- & tu- & ška & & & & & & \\
\hline & 0 & 0 & 0 & + & 0 & 0 & 0 & + & 0 & 0 & & & & & & \\
\hline
\end{tabular}

The distance between the prominences is three non-prominent morae, and one syllable takes sometimes a half-mora, so that two syllables complete one mora.

\section{VII-13 and VII-14 (Krasnopol'skaja 1987, 158-160)}

Laments VII-13 Visiting RELATIVES (the bride addresses her mother and her uncle) and VII-14 SAUNA (the bride laments the loss of her free maiden will) were performed by the same lamenter in 1886 in the village of Šun'ga. They have the same verse structure, the same musical meter $(2+4+4+2) / 8$ and the same metrical scheme. In Lament VII-13 each verse ends in an uncompleted word, dropped on the stressed syllable. In Lament VII-14 all final words are performed except those of the first two verses. On the basis of notation, a metrical mora can be acquired with a musical beat of 1/8 note. The metrical scheme of these laments is exemplified with verse 3 of Lament VII-13 and verse 1 of Lament VII-14.

(15) VII-13, verse 3 (the bride addresses her mother

before leaving to visit the relatives)

U-žó daj-ko mne ruc'-nó-e ru-ko-dé[-l'i-ce]

Give me handy handwork

VII-14, verse 1

Ot-pu-stí-te v te-plu-pár-nu me-njá bá-[enku]

Let me go to the warm sauna

\begin{tabular}{|l|l|l|l|l|l|l|l|l|l|l|l|l|}
\hline VII- & u- & žo & dáj- & ko & mne & ruc'- & nó- & e & ru- & ko- & dé- & {$[$ l'i-ce $]$} \\
\cline { 2 - 12 } $13(3)$ & 0 & 0 & + & 0 & 0 & 0 & + & 0 & 0 & 0 & + & oo \\
\hline VII- & o- & tpu- & stí- & te & v te- & plo- & pá- & rnu & me- & nja & bá- & [en-ku] \\
\cline { 2 - 12 } $14(1)$ & 0 & 0 & + & 0 & 0 & 0 & + & 0 & 0 & 0 & + & oo \\
\hline
\end{tabular}


In these two laments the verse has 12 morae, of them prominent, the $3 \mathrm{rd}$, the 7 th and the 11th morae. The distance between prominences is three non-prominent morae. The metrical pattern recurs from verse to verse: there are three non-prominent morae between the final prominence of one verse and the first prominence of the next one.

\section{VII-15 and VII-16 (Krasnopol'skaja 1987, 161-163)}

Laments VII-15 and VII-16 (1977, the village of Kosmozero) were recorded from different lamenters. In both laments a bride bids farewell to her free will. The laments have variable meter: of the notated 8 verses of Lament VII-15 and 8 verses of Lament VII-16 each one has different musical meter. Both laments are based on 1/8 musical beats. In both laments the first prominent is the third syllable, if we do not count the first short non-lexical one-syllable words and non-lexical syllables. It is better to ignore them in the metrical scheme because they are not always present. The procedure of finding the first prominence is as follows:

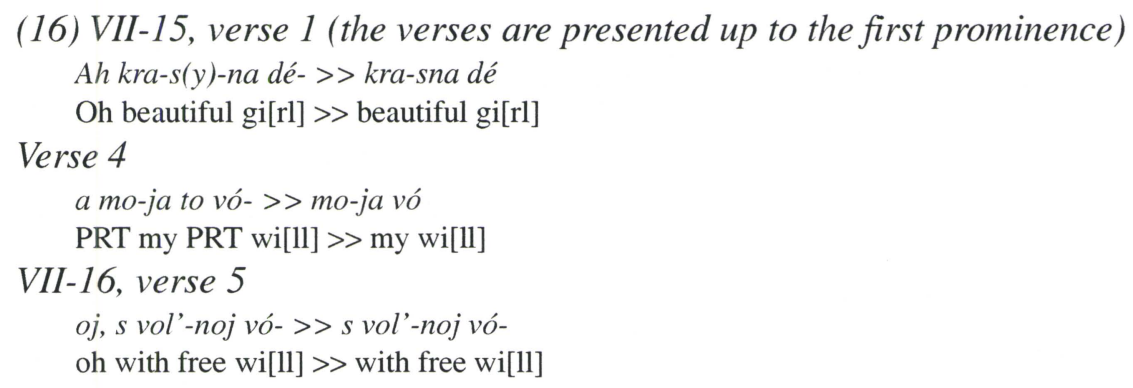

In Lament VII-15 the musical time preceding the first prominence varies from 2 to four musical beats while in Lament VII-16 this time is always 4 beats long. The final prominence is the third mora from the end. In the most verses of Lament VII-16 the last word is incomplete, dropped - as in many other laments - on the stressed syllable which constitutes the verse-final prominence. The notation shows that this prominence is followed by a $1 / 8$-note musical beat.

The performers of both laments tend to fill every musical beat with a syllable, lexical or non-lexical. The distance between prominent beats is mostly 3 or 5 beats. This is reasonable to construct a metrical scheme on the basis of three-mora distance between prominent morae, since this distance is supported by the syllable structure while non-lexical filling syllables in place of consonant clusters may be related to the rhyme, in other words, to a particular performance. The scheme is exemplified by verse 8 of VII-15 and verse 3 of VII- 16. 


\section{(17) VII-15 verse 8}

Mo-já vó-lju-ška vo nó-žen'-ki ska-tí-la-si

My will.dim has fallen down to my feet.dim

VII-16, verse 3

Oj, na s(y)-ve-tí-te-lja g(y)-la-zá da pe-rek(y)-re-stí-la

Oh, I have crossed myself before the Saint (icon).

\begin{tabular}{|c|c|c|c|c|c|c|c|c|c|c|c|c|c|c|c|c|c|c|}
\hline \multirow{2}{*}{$15(8)$} & \multicolumn{2}{|c|}{ mo- } & \multicolumn{2}{|l|}{ ja } & & & \multirow{2}{*}{$\begin{array}{l}\text { ška } \\
0 \\
\end{array}$} & & & & \multicolumn{2}{|c|}{ žen'- } & \multirow{2}{*}{$\begin{array}{l}\mathrm{ki} \\
0\end{array}$} & & & \multirow{2}{*}{$\begin{array}{l}\text { tí- } \\
+ \\
\end{array}$} & \multirow{2}{*}{\begin{tabular}{|l|l} 
la- \\
0 \\
\end{tabular}} & \multirow{2}{*}{\begin{tabular}{|l|l}
$\mathrm{si}$ \\
0
\end{tabular}} \\
\hline & 0 & & 0 & & & & & & & & 0 & & & & & & & \\
\hline $16(3)$ & oj & na & sy- & ve- & tí- & te- & lja & gy- & la- & zá & da & pe- & re- & ky- & re- & stí- & la & \\
\hline & 0 & 0 & 0 & 0 & + & 0 & 0 & o & 0 & + & 0 & 0 & 0 & 0 & 0 & + & 0 & \\
\hline
\end{tabular}

In verse 3 of VII-16 the pre-prominence four syllables are indicated to complete two morae. At the first glance this may appear a forced decision. Nevertheless, I am sure that the lament, as well as sung poetry in general, has a system in the verse structure. If there are non-lexical syllables and interjections in one verse which are lacking from the next verse, this does not mean that the verses are different, but only that the style of performance of these two verses is different, while they should be similar at the structural level:

(VII-16, verse 16, first three morae):

surface level: structural level:

oj na s(y)-ve-tí- na sve-tí-

Thus both laments have 13 morae long verse with 3 prominences, the $3 \mathrm{rd}$, 7th and 11th mora, and three non-prominent morae in-between.

\section{VII-17 and VII-18 (Krasnopol'skaja 1987, 163-165)}

Laments VII-17 and VII-18 were recorded in the same field work in the village of Lambasručej from the same lamenter. Some confusion arose during the editing of these two laments: the editor dated Lament VII-17 at 1884 and VII-18 at 1977 (Krasnopol'skaja 1987, 165). On the other hand, in the preliminary description of the appendix (ibid., 143), the lamenter of VII-17 is said to have been born in 1914 and Lament VII-18 is accounted for as recorded in 1984. It is clear that the recording of both laments took place either in 1977 or in 1984. Both VII-17 and VII-18 are LAMENTS OF THE GIRL WHO WARMS THE SAUNA FOR THE BRIDE. The laments differ by musical text and verse structure. In VII-17 the verse usually starts with one-syllable word, mostly the particle and conjunction $i$ 'and', and has the final word complete. In incomplete verse-final words the final syllable is lacking. In VII-18 two final syllables of the last word are systematically lacking and there are no particles in the beginning of the verse. There are 43 verses transcribed and the first 7 ones notated in VII-17, while 13 verses are trascribed and 5 notated in VII-18. Most verses of VII-18 are 
textually similar or very close to verses in VII-17. It seems that the singer lamented VII-17 first and afterwards demonstrated another way of treating the same topic by performing VII-18. Below there are the first three verses of each lament with the musical duration of each syllable subscribed. One musical beat is a $1 / 8$ note. The metrical scheme is exemplified with verses $1-2$ of both laments.

(18) VIII-17, 1-3 (musical meter $[4+5+5] / 8$ )

$\mathrm{Kak}_{2}$ ot ${ }_{1} \mathrm{be}_{1}-r e_{1}-\check{z} k a_{2} d o_{1} b e_{1}-r e_{1}-\check{z}(i)_{1}-k a_{1}$

As from coast to coast

$i_{1} t e_{1}-p(y)_{1}-l a a_{1} p a ́ r_{1}-n a(j)_{1} n a_{2}-\check{s} a_{1} j_{1} b a_{2}-e_{1}-n(y)_{1}[k a]$

PRT our PRT sauna is warm

$i_{1} t e_{1}-p(y)_{1}-l a_{1} p a ́ r_{1}-n a(j)_{1} n e_{2}-u_{1}-g a_{1}-r(y)_{1}-n a_{1}-j a_{1}$.

PRT warm and non-asphyxiated.

VII-18, 1-3 (musical meter [5+2]/4)

$K a k_{1} o t_{1} b e_{2}-r e-\check{z}(i)-k a_{4} d o_{2} b e_{2}-[r e-z ̌ k a]$

As from coast to coast

te - -pla - -pár $r_{2}-n a_{1} j_{1} n a_{4}-\check{s} a_{1} j_{1}$ bá $a_{2}$-[enka]

warm PRT our PRT sauna

te $e_{1}$-pla $a_{1}-$ pár $_{2}-n a_{1} j_{1} n e_{4}-u_{2}$-gár ${ }_{2}-[n a-j a$.]

warm PRT and non-asphyxiated.

\begin{tabular}{|c|c|c|c|c|c|c|c|c|c|c|c|c|c|}
\hline \multicolumn{2}{|l|}{$18-1$} & kak & ot & bé- & re- & ži- & $\mathrm{ka}$ & \multicolumn{2}{|l|}{ do } & bé-.. & & \\
\hline \multirow{2}{*}{\multicolumn{2}{|c|}{$18-2$}} & te- & pla & pár- & na & j & na- & ša & j & bá.. & & & \\
\hline & & 0 & 0 & + & 0 & 0 & 0 & 0 & 0 & + & $\varnothing$ & & $\varnothing$ \\
\hline \multirow[t]{2}{*}{$17-1$} & & kak & ot & bé- & \multicolumn{2}{|l|}{ re- } & žka & \multicolumn{2}{|l|}{ do } & bé- & re- & ži- & $\mathrm{ka}$ \\
\hline & $\varnothing$ & 0 & 0 & + & \multicolumn{2}{|l|}{0} & 0 & \multicolumn{2}{|l|}{0} & + & 0 & 0 & 0 \\
\hline \multirow[t]{2}{*}{$17-2$} & $\mathrm{i}$ & te- & py- & pár- & \multicolumn{2}{|c|}{ na(j) } & na- & \multicolumn{2}{|c|}{ ša(j) } & bá- & e- & ny.. & $\varnothing$ \\
\hline & 0 & 0 & 00 & + & \multicolumn{2}{|l|}{0} & 0 & \multicolumn{2}{|l|}{0} & + & 0 & 0 & $\varnothing$ \\
\hline
\end{tabular}

These laments have the same metrical pattern: the distance between prominences is 3 non-prominent morae. There are two prominences in a verse. The first prominence is the third mora in VII-18 and the fourth mora in VII-17. The final prominence of both laments is the third mora from the end. There is no one-to-one correspondence between musical beat and metrical mora for these laments: the second mora to the left from the final prominence is drawn out twice in comparison to the duration of the final prominent mora. In VII-17 the same drawing out is often applied to the second mora to the left from the first prominence. 


\section{Conclusions}

The analysis has shown that the metrical pattern of the poetic text tends to be permanent at least in one and the same lament. Several laments have similar patterns. The distance of three non-prominent morae between prominences is the most typical of the laments considered in this study. The positions of the first and the final prominences of a verse tend to be permanent counting from the beginning and from the end of the verse, even if the number of the non-prominent morae between prominences varies.

An exception to the regular metrical pattern was Lament VII-11, with the varying number of non-prominent morae and strict correspondence between metrical mora, musical beat and syllable. This correspondence suggests strong Finnic influence. This does not mean that other laments have not undergone influence. Multi-ethnical features can be found in musical text and at the linguistic level of the poetic text, but not necessarily in the metrical scheme. The same metrical scheme provides opportunities for different musical decisions (for instance, VII-17 and VII-18).

This pilot research is intended to raise scholarly interest in metrics of other genres of sung folk poetry as well as of the same genre performed in other regions. Further research will show if metrical schemes and patterns at surface level should be developed within one genre. The metrical scheme of the deep level is suggested to indicate similarities between poetic text of different genres. More than that - for further research a hypothesis can be proposed of a deep-level metrical pattern characteristic of the folk sung poetry of a whole region.

\section{Bibliography}

Agreneva-Slavjanskaja, O. H. 1887-1889. Opisanie russkoj svad'by. (Parts 1-3). Sankt-Petersburg - Tver'.

Bailey, J. 1989. The Metrical Invariant in a Russian Lyric Folk Song. Russian Verse Theory, eds. B. P. Scherr \& D. S. Worth, UCLA Slavic Studies, Vol. 18. Columbus, Ohio, USA: Slavica Publications, Inc. Pp. 23-56.

Banin, A. A. 1978. Ob odnom analitičeskom metode muzykal'noj fol'kloristiki. Muzykal'naja fol'kloristika 2, pp. 117-157.

Banin A. A. 1982. K izučeniju russkogo narodno-pesennogo stiha. Fol'klor: Poètika i tradicija 1981, ed. V. M. Gacak. Moskva: Nauka. Pp. 94-139.

Dütš, G. O. \& F. M. Istomin 1894. Pesni russkogo naroda. Sobrany v gubernijah: Arhangel'skoj i Oloneckoj $v 1886$ godu [Songs of Russian folk collected in the Archangel and Olonec governments in 1886], Sankt-Petersburg.

Kiparsky, P. \& G. Youmans (eds.) 1989. Rhythm and Meter (Phonetics and phonology; v. 1). San Diego, California, USA - London, UK: Academic Press, Inc.

Krasnopol'skaja, T. V. (ed.) 1987. Pesni Zaonež'ja v zapisjah 1880-1980 godov. General edition by E. V. Gippius. Leningrad: Sovetskij kompozitor.

Lysanov V. D. (ed.) 1916. Dosjul'naja svad'ba: pesni, igry i tancy v Zaonež'e Oloneckoj gubernii. [A wedding of old times: songs, plays and dances in Transonega of the Olonec governement] Musical notation by A. P. Maksimov. Petrozavodsk. 
Prince, A. 1989. Metrical Forms. Rhythm and Meter (Phonetics and phonology; v. 1), eds. Kiparsky, P. \& G. Youmans. San Diego, California, USA - London, UK: Academic Press, Inc. Pp. 45-80.

Rozental', D. Ė. (ed.) 1979. Sovremennyj russkij jazyk. Parts I and II. Moskva: Vysšaja škola.

Trubetzkoj, N. 1987/1927. O metrike častuški. Izbrannye trudy po filologii, Moskva: Progress. Pp. 371390.

Žirmunskij,V. 1975. Teorija stiha. Leningrad: Sovetskij pisatel'. 